ISSN 0258-7122

Bangladesh J. Agril. Res. 40(4): 711-715, December $2015 \quad$ Short Communication

\title{
EFFICACY OF FUNGICIDES AND BOTANICALS IN CONTROLLING FOOT AND ROOT ROT OF LENTIL
}

\author{
MD. SHAHIDUZZAMAN ${ }^{1}$
}

Lentil (Lens culinaris Medik) is the second most important pulse crop in terms of both area and production (Anon., 2014). In Bangladesh pulses constitute an integral part of the daily diet as a direct source of protein for human beings (Sattar et al., 1996). Consumption of lentils with small grains provides a balanced diet. It is a cheap source of protein for human beings and also for animals in Bangladesh (Sattar et al., 1996). Lentil is also important in crop diversification in the cropping systems of the country. As the price of animal protein is increasing day by day, the protein shortage in the diet system of the people in the country can be met up through lentil. The yield of lentil in Bangladesh is low which is associated with poor management practices, unavailability of quality seeds and especially lack of proper disease management options. Diseases play important role for yield reduction. Lentil is affected by a wide range of fungal diseases. Productivity of lentil is reduced by pathogens through infection and damage to leaves, stems, roots and pods. It also reduces marketability due to discoloration of the seeds. Lentil suffer from attack of a number of seed borne diseases such as vascular wilt, collar rot, root rot, stem rot, rust, powdery mildew and downy mildew, which are caused by Fusarium oxysporum f. sp. lentis, Sclerotium rolfsii, Rhizoctonia solani, Uromyces fabae, Erysiphe polygoni and Peronospora lentis, rspectively (Khare et al., 1979, Singh and Tripathy, 1999). The soil borne pathogens Fusarium oxysporum and Sclerotium rolfsii commonly occur in the tropics and sub-tropics of the world causing foot and root rot of many crops (Aycock, 1966).

Foot and root rot caused by Fusarium oxysporum and Sclerotium rolfsii is considered as an important and destructive disease of pulses in almost all legume-growing countries of the world including Bangladesh (Anon., 1986, Dey et al., 1993). In Bangladesh, about $44 \%$ lentil plants are infected by foot and root rot disease (Anon., 1986). It causes seedling death at early stage resulting very poor plant stand which ultimately produces very low yield.

Despite of the many achievements in modern agriculture, chemical control still holds a strong performance in combating certain destructive plant diseases. Farmers' use chemicals for controlling the diseases of crop plants in Bangladesh, but limited information on the efficacy of these chemicals exits in our country (Hoque et al., 2014). Considering the above facts the present study was undertaken to evaluate efficacy of fungicides and botanicals for controlling foot and root rot of lentil under field condition at Madaripur district of Bangladesh.

${ }^{1}$ Scientific Officer, Regional Pulses Research Station, Bangladesh Agricultural Research Institute (BARI), Madaripur, Bangladesh. 
The experiment was carried out at Regional Pulses Research Station of Bangladesh Agricultural Research Institute (BARI), Madaripur, in the cropping seasons of 2011-12 and 2012-13. Seeds of lentil variety BARI masur-1 susceptible to foot and root rot has been used in the study. The experiment plot was prepared mechanically. Weeds and other materials were removed. The soil was prepared into good tilth by four cross ploughings and ladderings. The soil of the field was leveled before seed sowing. Fertilizers such as Urea, TSP and MOP were applied @ 45,85 and 35 kg/ha and Cowdung @ 5 ton/ha during final land preparation (Anonymous, 2005). The experiment was laid out in randomized complete block design with three replications. Each block was divided into seven experimental units. The size of each experimental unit was $4 \mathrm{~m} \times 3 \mathrm{~m}$. The treatments were assigned in each block at random. Three fungicides and three botanicals were used as seed treatment with one untreated control. The lentil seeds were sown in furrows made with tine where distance between the furrows was $30 \mathrm{~cm}$.

The fungicides and botanicals tested in the experiment were Provax 200 (Carboxin + Thiram), Bavistin $50 \mathrm{WP}$ (Carbendazim), Trichoderma compost (3 t/ha), Neem leaf extract $(1: 4 \mathrm{w} / \mathrm{v})$, Garlic clove extract $(1: 4 \mathrm{w} / \mathrm{v})$, Allamanda leaf extract $(1: 4 \mathrm{w} / \mathrm{v})$ and control (untreated seed). Garlic bulb, allmanda and neem leaf extracts were prepared separately by crushing the cloves and leaves with the help of a mortar and pestle. The crushed materials were blended in an electric blender for fresh extract, and required amount of sterile water was added at 1:1 for solution. The blend was filtered through sterile cheesecloth. The supernatant was mixed with carrier material (flour). The mixture was put into wooden pellet device, thus the tablets of Garlic (Allium sativum), allamanda (Allamanda cathertica) and neem (Azadiracta indica) were prepared separately. These tablets were melted in 1:4 $(\mathrm{w} / \mathrm{v})$ concentration before seed treatment. The required amounts of seeds for each sub plot were taken in ployethylene bags, mixed with fungicides or botanicals and then sown at a rate of $40 \mathrm{~kg} / \mathrm{ha}$ in the furrows immediately. The Trichoderma compost was applied in the plot before seed sowing.

Intercultural operations were done whenever, necessary and weeding was performed two times during the growing period of the crop. One weeding was done at 20 days and another at 35 days after sowing. During the growing period the plots were inspected regularly to record the foot and root rot disease. Dead plants were removed from the field after counting. Infected 5 plants were collected to identify foot and root rot pathogens.

The incidence of foot and root rot of lentil was recorded at 10 days interval. The incidence of the disease was calculated by the following formula:

Incidence $(\%)=\frac{\text { Number of infectedplants }}{\text { Totalnumber of plants }} \times 100$ 
Data on growth parameters were recorded from 10 randomly selected plants in each plot. The crop was harvested on 10 March in 2012 and 09 March in 2013. Grain yield were determined based on the whole plot and expressed in kilogram per hectare. The recorded data were analyzed statistically. Analysis of Variance and LSD test were done to find out the significant difference among the treatment means (Zaman et al., 1982).

Plant mortality, number of pod per plant and yield ranged from 7.06-10.90\%, 49.33-74.33 and 1063-1465 kg/ha, respectively under various treatments during 2011-2012 cropping seasons (Table 1). The highest mortality (10.90\%) was recorded from the control plot. The lowest reduction was obtained with allamanda leaf extract followed by garlic clove extract and neem leaf extract. The reduction of disease severity under Bavistin 50WP and Trichoderma compost was similar. The maximum and significant reduction was achieved with only Provax 200 compared to control. The highest (74.33) number of pod was achieved from Provax 200 which was statistically similar to Bavistin 50WP (70.00) and the lowest (49.33) pod number was found under control plot (Table 1). The highest yield $(1465 \mathrm{~kg} / \mathrm{ha})$ of lentil grain was recorded from Provax 200 and lowest yield $(1063 \mathrm{~kg} / \mathrm{ha})$ form control. All treatments with fungicides as well as botanicals increased the crop yield significantly over control. The highest increase (37.82\%) was achieved with Provax 200 followed by Trichoderma compost (30.10\%) and Bavistin 50WP (23.89\%).

Table 1. Efficacy of fungicides and botanicals in controlling foot and root rot disease of lentil during rabi 2011-2012 at PRRS, Madaripur.

\begin{tabular}{l|c|c|c|c}
\hline \multicolumn{1}{c|}{ Treatment } & $\begin{array}{c}\text { Plant } \\
\text { mortality }(\%)\end{array}$ & $\begin{array}{c}\text { No. of pods } \\
\text { per plant }\end{array}$ & $\begin{array}{c}\text { Yield } \\
(\mathrm{kg} / \mathrm{ha})\end{array}$ & $\begin{array}{c}\text { Yield increase } \\
\text { over control } \\
(\%)\end{array}$ \\
\hline Provax 200 @ 2\% & 7.06 & $74.33 \mathrm{a}$ & $1465 \mathrm{a}$ & 37.82 \\
Bavistin 50 WP @ 2\% & 8.23 & $70.00 \mathrm{ab}$ & $1317 \mathrm{bc}$ & 23.89 \\
Trichoderma compost @ 3 t/ha & 8.23 & $67.33 \mathrm{bc}$ & $1383 \mathrm{ab}$ & 30.10 \\
Neem leaves extract (1:4 w/v) & 8.86 & $63.67 \mathrm{bcd}$ & $1315 \mathrm{bc}$ & 23.70 \\
Garlic clove extract (1:4 w/v) & 9.16 & $61.00 \mathrm{~cd}$ & $1256 \mathrm{~cd}$ & 18.16 \\
Allamanda leaf extract (1:4 w/v) & 9.36 & $57.33 \mathrm{~d}$ & $1195 \mathrm{~d}$ & 12.42 \\
Control & 10.90 & $49.33 \mathrm{e}$ & $1063 \mathrm{e}$ & - \\
\hline CV(\%) & 5.32 & 5.94 & 3.99 & - \\
LSD(0.05) & 0.83 & 6.68 & 91.25 & - \\
\hline
\end{tabular}

Values within a column having a common letter(s) do not differ significantly $(\mathrm{P}=0.05)$. 
Plant mortality, number of pod per plant and yield also significantly varied among the treatments including control during 2012-2013. The highest \% mortality was recorded from control (Table-2). Treatments with different fungicides reduced disease severity as compared to control. The lowest reduction was obtained with garlic clove extract followed by allamanda leaf extract and neem leaf extract. The reduction of disease severity under Bavistin 50WP and Trichoderma compost was identical. The maximum and significant disease reduction was achieved with Provax 200 compared to other treatments. The highest number (66.33) of pod was achieved from Provax 200 which was statistically similar with Bavistin 50WP (62.00) and Trichoderma compost (59.67) treated plot and the lowest (43.67) pod number was found under control (Table-2). The highest yield $(1322 \mathrm{~kg} / \mathrm{ha})$ of lentil grain was recorded from Provax 200 and lowest yield $(963.30 \mathrm{~kg} / \mathrm{ha})$ from control. The highest yield increase (37.24\%) was achieved with Provax 200 followed by Bavistin 50WP (34.23\%) and Trichoderma compost (29.24\%). The effect of Provax 200 on crop yield was significantly higher over other treatments where Bavistin 50WP and Trichoderma compost are statistically identical (Table 2).

Table 2. Efficacy of fungicides and botanicals in controlling foot and root rot disease of lentil during rabi 2012-2013 at PRRS, Madaripur.

\begin{tabular}{l|c|c|c|c}
\hline \multicolumn{1}{c|}{ Treatment } & $\begin{array}{c}\text { Plant } \\
\text { mortality } \\
(\%)\end{array}$ & $\begin{array}{c}\text { No. of pods } \\
\text { per plant }\end{array}$ & $\begin{array}{c}\text { Yield } \\
(\mathrm{kg} / \mathrm{ha})\end{array}$ & $\begin{array}{c}\text { Yield increase } \\
\text { over control } \\
(\%)\end{array}$ \\
\hline Provax 200 @ 2\% & 7.30 & $66.33 \mathrm{a}$ & $1322 \mathrm{a}$ & 37.24 \\
Bavistin 50 WP @ 2\% & 9.33 & $62.00 \mathrm{ab}$ & $1293 \mathrm{ab}$ & 34.23 \\
Trichoderma compost @ 3 t/ha & 9.40 & $59.67 \mathrm{abc}$ & $1245 \mathrm{ab}$ & 29.24 \\
Neem leaves extract (1:4) & 10.60 & $57.00 \mathrm{bc}$ & $1188 \mathrm{bc}$ & 23.33 \\
Garlic clove extract (1:4) & 11.00 & $54.33 \mathrm{~cd}$ & $1123 \mathrm{c}$ & 16.58 \\
Allamanda leaf extract(1:4) & 11.60 & $50.00 \mathrm{de}$ & $1101 \mathrm{c}$ & 14.29 \\
Control & 12.90 & $43.67 \mathrm{e}$ & $963.30 \mathrm{~d}$ & - \\
\hline CV(\%) & 6.48 & 6.60 & 4.93 & - \\
LSD(0.05) & 1.18 & 6.58 & 103.2 & - \\
\hline
\end{tabular}

Values within a column having a common letter(s) do not differ significantly ( $\mathrm{P}=0.05)$.

It was quite evident that foot and root rot of lentil caused by Fusarium oxysporum and Sclerotium rolfsii had immense impact on germination, disease incidence, seedling mortality and yield (Dey et al., 1993). From the result it was observed that seed treatment with all the tested fungicides/ botanicals reduced the disease severity and increased pod number and crop yield of lentil as compared to untreated control. Provax 200, Bavistin 50WP and Trichoderma compost showed better performance than other treatments in both the seasons. However, 
in 2011-12 cropping season, Bavistin 50WP, Trichoderma compost and Neem leaf extract showed statistically identical mortality, pods per plant and yield while in 2012-13 cropping season, Bavistin 50WP and Trichoderma compost showed statistically similar results.

The result of the present study clearly indicated that, seed treatment with botanicals and fungicides promoted yield by reducing foot and root rot disease.

\section{References}

Anonymous. 1986. Annual Report 1985-86. Plant Path. Div. BARI, Gazipur, P-19.

Anonymous. 2005. Dal fasol utpadon poddoti. BARI Hand book, P. 101-104.

Anonymous. 2014. Acrage and Production of Pulse Crops. Agricultural Information Service, Krishi Diary, Department of Agricultural Extension, Bangladesh, P-14.

Aycock, R. 1966. Stem rot and other diseases caused by S. rolfsii. Tech. Bull. No. 174. Agric. Expt. Station, North Carolina State University, Raleigh, P. 202.

Dey, T. K., M. S. Ali and N. Chowdhury. 1993. Vegetative growth and sporangia production in Phytophthora colocaseae. Indian J. Root Crops 17(2): 142-146.

Hoque, M. A., I. Hamim, M. R. Haque, M. A. Ali, M. Ashrafuzzaman. 2014. Effect of Some Fungicides on Foot and Root Rot of Lentil. Universal J. Plant Science 2(2): 52-56.

Khare, M. V., S. C. Agrawal and A. C. Jain. 1979. Diseases of lentil and their control. Tech. Bull.. Jabalpur, Madhya Prasesh, India: Jawaharlal Nehru Krisi Viswa Vidyalaya.(http://www.hrpub.org).

Sattar, M. A., A. R. Podder, M. C. Chandra and M. Rahman. 1996. The most promising BNF technology for green legume production in Bangladesh. BNF Association, Dhaka, BD. 28 Nov 1994, Pp.15-20.

Singh, J. and S. C. Tripathy. 1999. Mycoflora association with stored seeds of Lens esculenta. Herbal Pesticide Lab., Dept. of Botany, Gorakhpur Univ. Gorakhpur. India. (http://www.hrpub.org)

Zaman, S. M. H., K. Rahim and M. Howladar. 1982. Simple lessions from biometry. Bangladesh Rice Research Institute, Joydebpur, Gazipur. Publication No. 54. (http://www.hrpub.org). 